\title{
Chemical composition and antimicrobial properties of different basil essential oils chemotypes from Togo
}

\author{
Koffi Koba' ${ }^{1}$ P.W. Poutouli², Christine Raynaud3, Jean-Pierre Chaumont ${ }^{4}$ and \\ Komla Sanda ${ }^{1}$
}

${ }^{1}$ Unité de Recherche sur les Agroressources et la Santé Environnementale, Ecole Supérieure d'Agronomie, Université de Lomé, BP. 1515, Lomé Togo; '2Département de Biologie Animale et de zoologie, Faculté des Sciences, Université de Lomé, B.P. 1515 Lomé Togo; '3aboratoire de Chimie Agro-Industrielle, UMR 1010, INRA/INPENSIACET, 118, route de Narbonne, 31077 Toulouse cedex, France; ${ }^{4}$ Equipe des Sciences Séparatives et Biopharmaceutiques EA 3924, Université de Franche-Comté, Faculté de Médecine et de Pharmacie, Place SaintJacques, 25030, Besançon, Cedex France.

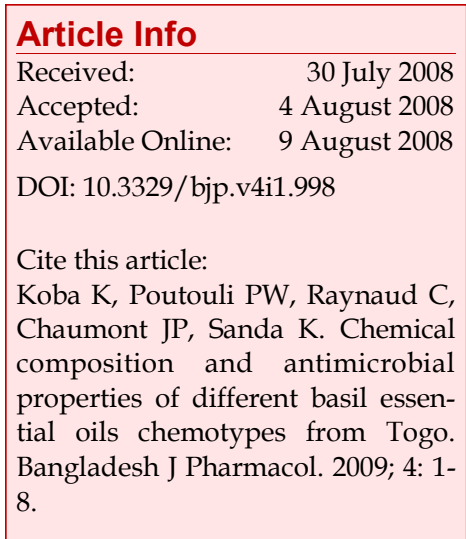

\section{Abstract}

The aerial parts essential oils of Ocimum basilicum (Lamiaceae) from Togo were steam-distilled and investigated for their percentage composition (GC and GC) MS) and in vitro antimicrobial activities. Five oil chemotypes were identified and classified as follows in line with their principal components: Estragole type; linalool/estragole type; methyleugenol type; methyleugenol/t-anethole type; $\mathrm{t}$ anethole type. The in vitro microbiological experiments revealed that only the methyleugenol and methyleugenol/t-anethole chemotypes were active against tested fungi and bacteria. Their minimum inhibitory concentrations (MIC) ranged from $80-150 \mu \mathrm{L} / \mathrm{L}$ and from $200-500 \mu \mathrm{L} / \mathrm{L}$ respectively. Likewise, on tested bacteria the MIC varied from $200-400 \mu \mathrm{L} / \mathrm{L}$ and from $250-500 \mu \mathrm{L} / \mathrm{L}$ respectively. These findings are supportive of the potential of both basil oil chemotypes for use as active ingredients in natural antibiotic drugs.

\section{Introduction}

The genus Ocimum collectively called basil (in English), includes around 30 plant species from tropical and subtropical areas (Paton, 1992). Ocimum is widely cultivated and extensively used for food, perfumery, cosmetics, pesticides, medicine, and traditional rituals because of their natural aroma and flavor and other properties (Alburquerque, 1996; Darrah, 1974). Literature reports that $O$. basilicum leaf essential oils or leaf powder have effective insecticidal and pesticidal actvities against Vigna unguiculata pests Callosobruchus maculatus (F) (Coleoptera: Bruchidae) (Keita et al., 2001; Ketoh et al., 2002). O. basilicum commonly grows semiwild and is cultivated in Togo at small scale in vegetable gardens. Current domestic uses are only for food and folk medicine (Adjanohoun et al., 1986).
Nevertheless, a large scale production of the basil essential for well-known value-added applications (Berrada et al., 1987; Archtander, 1994) is quite viable under local circumstances.

The chemical composition of O. basilicum essential oils has been intensively investigated throughout the world (Ekundayo et al., 1987; Sanda et al., 1998; Yayi et al., 2001), indicating that the estragole chemotype and the linalool -estragole one are the most widely distributed.

At the same time, only very little work has been done on the chemical composition and the antimicrobial activities of basil oils from plants growing in Togo (Sanda et al., 1998; Koumaglo et al., 1996). In addition, there are very few data available either for practical use or for basic research needs about antimicrobial properties of the essential oils of O. basilicum growing 
in Togo (Baba-Moussa et al., 1997; Chaumont et al., 2001).

In order to help fill this deficiency, partly at least, the aim of the present work was to investigate basil oils extract of plants sampled in different localities belonging to different ecological areas of Togo. Specifically, oils percentage composition was determined along with their bacteriostatic and fungistatic activity using 14 bacterial and 14 fungal strains.

The principal finding expected from this applied research is the candidate basil oil(s) that could be produced in Togo for use as source(s) of active ingredients in natural antibiotics or cosmetics.

\section{Materials and Methods}

\section{Plant material sampling and volatile oils isolation}

Leaves and inflorescences of $O$. basilicum used in this work were harvested from plants at full flowering stage in vegetable gardens in five various locations of Togo from May to October 2007.

Plant specimen was identified by Prof. Akpagana, Departement de Botanique, Faculté des Sciences at the Université de Lomé (Togo), where voucher specimens were deposited in the herbarium.

A sample (50 g) of air-dried plant material was extracted by the hydrodistillation technique during 2 hours in a modified Clevenger-type glass apparatus (Craveiro et al., 1976). The extracted crude essential oils were stored in hermetically sealed dark glass flasks with rubber lids, covered with aluminium foil to protect the contents from light and kept under refrigeration at $4^{\circ} \mathrm{C}$ until use without any prior purification.

\section{Essential oil analyses by gas chromatography}

Gas chromatographic analysis was carried out on a Varian 3300 type gas chromatograph equipped with FID detector. An apolar capillary column DB-5 (30 m x $0.25 \mathrm{~mm}$ i.d.; film thickness $0.25 \mu \mathrm{m}$ ) and on a polar column supelcowax 10 with the same characteristics as above mentioned were used. DB- 5 column operating conditions were as follows: From $50^{\circ} \mathrm{C}$ ( $\left.5 \mathrm{~min}\right), 50$ to $250^{\circ} \mathrm{C}$ at the rate of $2^{\circ} \mathrm{C} / \mathrm{min}$ and supelcowax 10 from $50^{\circ} \mathrm{C}$ (5 min), 50 to $200^{\circ} \mathrm{C}$ at $2^{\circ} \mathrm{C} / \mathrm{min}$. The injector and detector temperatures were respectively 250 and $300^{\circ} \mathrm{C}$. The carrier gas was helium at a flow rate of $1.5 \mathrm{~mL} /$ min. Samples $(0.2 \mu \mathrm{L})$ of undiluted essential oil were injected manually.

\section{Gas chromatography-mass spectrometry analysis}

The GC/MS analysis was carried out on a Hewlett
Packard 5890 series II chromatograph, coupled with a mass spectrometer of the Hewlett Packard 5971 series type operating in the EI mode at $70 \mathrm{eV}$. The capillary column type was DB5-MS (30 m x $0.25 \mathrm{~mm}$ i.d.; film thickness $0.25 \mu \mathrm{m})$. The amount of sample injected and GC/MS parameters were the same as above.

\section{Identification of components}

The components of oils samples were identified by their retention time, retention indices relative to $\mathrm{C}_{8}-\mathrm{C}_{24}$ $n$-alkanes, computer matching with Wiley 275L library and as well as by comparison of their mass spectra with the authentic samples or with data already available in the literature (Kondjoyan and Berdagué, 1996; Adams, 2001).

The percentage of composition of the identified compounds was computed from the GC peak area without any correction factor and was calculated relatively.

\section{In vitro antifungal testing}

Fungal strains used are listed in Table I. They were supplied by Institut Pasteur de Paris and Hôpital Saint Jacques de Besançon, France. The fungi were cultivated on a sabouraud agar medium in which was added chloramphenicol 1\%, all purchased from BioMerieux Co. (Paris, France). Pure estragole, linalool and methyleugenol commercial standards were also purchased from BioMerieux Co. (Paris, France).

The antimicrobial activities of the essential oils were assessed according to agar dilution method (Benjilali et al., 1986; Griffin et al., 2000). The tested essential oil and its pure major components from commercial origin were diluted in a minimal quantity of ethanol 95\% 1/10 $\mathrm{v} / \mathrm{v}$ to which was added an aqueous solution of Tween 80 (final concentration of $1 \% \mathrm{v} / \mathrm{v}$ ) in order to obtain a homogeneous mixture. The later was incorporated as appropriate to the microbiological culture medium under solidification to obtain final concentrations of the active ingredient that ranged from 10 to $500 \mu \mathrm{L} / \mathrm{L}$. The mixture was then poured into $3 \mathrm{~cm}$ diameter petri dishes.

After solidification fungal strains were respectively seeded as described below:

(i) dermatophytes were seeded with a disc of approximately $2 \mathrm{~mm}$, from a mycelia carpet of preculture, laid in the middle area of a new petri dishes, upper side against the new culture medium;

(ii) $1 \mathrm{~mL}$ of a suspension of $10^{5}$ conidia per $\mathrm{mL}$ of Aspergillus fumigatus or $10^{5}$ blastospores per $\mathrm{mL}$ of yeast was poured on the surface of the culture medium. Incubation time and temperatures depended on the fungal strains: 24 hours at $37^{\circ} \mathrm{C}$ for Candida albicans and Aspergillus, 48 hours at $37^{\circ} \mathrm{C}$ for Cryptococcus, 14 days at 


\begin{tabular}{|c|c|c|c|c|c|c|c|c|}
\hline \multicolumn{9}{|c|}{ Table I } \\
\hline \multicolumn{9}{|c|}{ Antifungal activities of different $O$. basilicum essential oils chemotypes from Togo } \\
\hline \multirow[t]{3}{*}{ Fungal strains } & \multicolumn{8}{|c|}{$\mathrm{MIC}^{*}(\mathrm{~mL} / \mathrm{L})$} \\
\hline & \multicolumn{5}{|c|}{ Basil oils chemotypes } & \multirow[t]{2}{*}{ Linalool } & \multirow{2}{*}{$\begin{array}{c}\text { Méthyl } \\
\text { eugenol }\end{array}$} & \multirow[t]{2}{*}{ Estragole } \\
\hline & $\mathrm{Ob}^{1 *}$ & $\mathrm{Ob}^{2 *}$ & $\mathrm{Ob}^{3 *}$ & $\mathrm{Ob}^{4 *}$ & $\mathrm{Ob}^{5 *}$ & & & \\
\hline \multicolumn{9}{|l|}{ Dermatophytes } \\
\hline Trichophyton mentagrophytes (B) & $>500$ & 400 & 80 & 250 & $>500$ & $>500$ & 60 & $>500$ \\
\hline T. interdigitale $(\mathrm{B})^{*}$ & $>500$ & 450 & 100 & 300 & $>500$ & $>500$ & 150 & $>500$ \\
\hline T. rubrum $(\mathrm{B})$ & $>500$ & 400 & 150 & 300 & $>500$ & $>500$ & 150 & $>500$ \\
\hline T. soudanense $(\mathrm{B})$ & $>500$ & 500 & 100 & 200 & $>500$ & $>500$ & 300 & $>500$ \\
\hline T. violaceum (B) & 500 & 500 & 100 & 300 & $>500$ & 450 & 300 & 500 \\
\hline Microsporum canis $(\mathrm{CIP})^{*}$ & $>500$ & 400 & 200 & 300 & $>500$ & 600 & 150 & $>500$ \\
\hline Microsporum gypseum (CIP) & $>500$ & 500 & 200 & 250 & 500 & 500 & 150 & $>500$ \\
\hline Epidermophyton flocosum (B) & $>500$ & 500 & 200 & 300 & $>500$ & 500 & 200 & $>500$ \\
\hline \multicolumn{9}{|l|}{ Imperfect filamentous fungi } \\
\hline Aspergillus fumigatus (B) & $>500$ & $>500$ & 150 & 500 & $>500$ & $>500$ & 600 & $>500$ \\
\hline Scopulariopsis brevicaulis (B) & $>500$ & $>500$ & 100 & $>500$ & $>500$ & $>500$ & 500 & $>500$ \\
\hline Scytalidium dimidiatum (B) & $>500$ & $>500$ & 150 & $>500$ & $>500$ & $>500$ & $>500$ & $>500$ \\
\hline Scytalidium hyalinum (B) & $>500$ & $>500$ & 200 & $>500$ & $>500$ & $>500$ & $>500$ & $>500$ \\
\hline \multicolumn{9}{|l|}{ Pathogenic yeasts } \\
\hline Candida albicans (B) & $>500$ & $>500$ & 80 & 500 & $>500$ & $>500$ & 100 & $>500$ \\
\hline Cryptococcus neoformans (B) & $>500$ & $>500$ & 100 & 400 & $>500$ & $>500$ & 100 & $>500$ \\
\hline
\end{tabular}

$24^{\circ} \mathrm{C}$ for the dermatophytes and Scopulariopsis brevicaulis.

\section{Antibacterial testing}

Bacterial strains were supplied by Institut Pasteur Collection de Paris and Leeds University Microbiology Laboratory, United Kingdom. They were cultivated on $1.3 \%(\mathrm{~m} / \mathrm{v})$ nutrient broth-agar-granulated (NB-AG) culture medium (AES Labortories), in $9 \mathrm{~cm}$ diameter petri dishes. After cooling and solidification, the petri dishes were automatically inoculated with the bacterial suspensions $10^{5} \mathrm{CFU} / \mathrm{mL}$ with STEERS apparatus. The petri dishes were incubated at $37^{\circ} \mathrm{C}$ for 48 hours under aerobic conditions.

Major constituents: Others meaningful constituents were estragole $(10.0 \%),(E)$-a-bergamotene $(3.6 \%)$ and linalool $(2.9 \%)$.

v) $\mathrm{t}$-Anethole chemotype (sample from Bassar): This sample contained mainly t-anethole $(74.6 \%)$, linalool $(17.3 \%)$ and carvacrol $(2.7 \%)$.

To our knowledge, the last three basil oil chemotypes have not yet been reported. O. basilicum has been thoroughly investigated with regards to volatile oil composition but some of our findings are supportive of the idea that continuing chemical inventory on this species is still of scientific interest to support action aimed at plant biodiversity knowledge, conservation and sustainable exploitation.

The findings on the chemical composition of basil oils in Togo were very instructive with regard to the possible applications. Hence, the estragole chemotype found here resembled that described by Ekundayo et al. (1987) and Baritaux et al. (1992), which is well-known for its valuable usage in perfumery and food (Kayibou, 1992). In addition, this chemotype has been recently indicated as a possible pesticide against larva and adult of Callosobruchus maculatus known as a major postharvest pest of Vigna unguiculata in storage (Keita et al., 2001; Ketoh et al., 2002).

The pesticidal activity of the volatile oil of Clausena anisata, containing mainly estragole and t-anethole (Moudachirou et al., 1997; Okunde and Olaifa, 1987). Such indications on the pesticidal properties of this essential oil containing estragole and $t$-anethole is certainly indicative of the biocide potential of these natural molecules which might be endowed with antimicrobial properties (Friedman et al., 2002), our focus in this investigation. 
imperfect filamentous fungi were also highly sensitive to the test volatile oil; MICs were in the range of 100$150 \mu \mathrm{L} / \mathrm{L}$. Likewise, the methyleugenol oil chemotype appeared very toxic to pathogenic yeast strains including Candida, Cryptococcus, Aspergillus, and Scopulariopsis, MICs varying from 80 to $100 \mu \mathrm{L} / \mathrm{L}$. Also noticeable was the antifungal effect (MIC: $150 \mu \mathrm{L} / \mathrm{L}$ and $200 \mu \mathrm{L} / \mathrm{L}$ ) of this oil chemotype on both strains of Scytalidium sp. The later, which often resist conventional antibiotics, are usually reported in human dermatomycosis in tropical and subtropical countries (Alvarez et al., 2000). The African Trichophyton soudanense, a parasite frequent in school environment (Ouaffak et al., 2001; Vandemeulebroucke et al., 1999) was interestingly also sensitive to the tested essential oils (MICs 100 and $200 \mu \mathrm{L} / \mathrm{L}$ ). It was also the case for Cryptococcus neoformans, a hazardous opportunist yeast, which is a resistant germ usually infecting humans affected by HIV/AIDS, which group of patients is known to be generally at high-risk with regard to mycosis opportune affections.

The high antifungal activity of this basil oil chemotype on those pathogenic fungi like dermatophytes, filamentous fungi and yeasts confirmed the excellent fungal growth inhibition properties previously reported as a characteristic of essential oils rich in methyleugenol and/or other phenol derivatives (Chaumont and Leger, 1989). In this work there is no doubt that the antifungal activity of $O$. basilicum chemotype methyleugenol against tested fungi is a predictable consequence of its high content in methyleugenol known as one of the phenolic volatile molecules endowed with antimicrobial properties (Chaumont and Leger, 1989; Viollon and Chaumont, 1994). In comparison, commercial linalool and estragole tested as standards in this study were found noneffective unlike pure methyleugenol standard.

The methyleugenol/t-anethole chemotype showed a moderate antifungal activity only on dermatophytes with MICs ranged from 250-300 $\mu \mathrm{L} / \mathrm{L}$ but not filamentous fungi and yeasts were not affected. The estragole type, the linalool/estragole type, and the $\mathrm{t}$ anethole type were ineffective on all fungal strain tested in this work. A lesson learned from the findings mentioned above was that estragole and t-anethole, which are reported as possible natural pesticides, could not serve as natural fungicidal ingredients unlike methyleugenol against the fungal strains tested in this work. This simply indicates the broader understanding of what is generically termed to as the biological activity of essential oils.

Table III shows that all feet microflora bacterial strains tested were only sensitive to methyleugenol and methyleugenol/t-anethole oil chemotypes.

The MICs, which were in the range of $200-500 \mu \mathrm{L} / \mathrm{L}$ were slightly higher than those recorded on fungal strains in this study, indicating a lesser activity. The results recorded against common armpit microflora bacterial strains, were especially promising for a possible use against Corybacterium xerosis, the principal one of the bacteria responsible for bad odors. Its growth was interestingly inhibited with at a dose of $100 \mu \mathrm{L} / \mathrm{L}$ antibacterial test suspension. Note that this bacteria metabolizes human steroids produced via transpiration to yield small and bad-smelling volatile molecules (Rennie et al., 1991).

The findings in this study indicated bacteriostatic effects against feet microflora germs like Staphylococcus epidermidis and Staphylococcus hominis (MIC: 200 and $300 \mu \mathrm{L} / \mathrm{L}$ ) partly responsible for feet bad odors (Marshall et al., 1987; Marshall et al., 1988). Methyleugenol and methyleugenol/t-anethole oil chemotypes samples were also very active against the Coryneform (Corynebacterium gr B, C and D2) (MIC: From 100-300 $\mu \mathrm{L} / \mathrm{L}$ ) which produce proteinase and lipase, both enzymes that cause feet surface skin bad odors (Marshall et al., 1987; Marshall et al., 1988). Both oil chemotypes also showed a moderate antibacterial activity against gram negative bacteria (Acinetobacter sp, Moraxella sp: MIC from 250- $500 \mu \mathrm{L} / \mathrm{L}$ ) and gram positve bacteria (Micrococcus luteus, Staphylococcus epidermidis: MIC: From 200-500 $\mu \mathrm{L} / \mathrm{L})$. The later are involved in nosocomial infections (Bergogne-Bérézin, 1995; CDC, 1999).

The proven antibacterial activities of the methyleugenol and metyleugenol/t-anethole types of basil oil found in this study are quite indicative of their potential as possible active ingredients for use in the formulation of deodorants for armpits or feet. Developing sustainable large scale consumer goods like natural drugs and cosmetics based on basil oil as well as on other essential oils bearing aromatic plants growing in Togo is of an obvious economic interest while helping preserve plant biodiversity.

Culture media with or without ethanol $95 \%$ and Tween 80 were used as controls.

The antimicrobial activities were evaluated by the determination of the minimum inhibitory concentration (MIC). The MIC of a tested active ingredient was determined as the lowest concentration of the test antimicrobial ingredient sample that resulted in a complete inhibition of visible growth of the microorganisms. All tests were carried out in triplicate.

\section{Results and Discussion}

Basil oil extraction yields were in the range of $1.4 \%$ to $2.2 \%$, based on plant material dry weight. Identified oil constituents and percentage and their relative 


\section{Table II}

\section{Chemical composition of O. basilicum volatile oils from Togo}

Identified compounds*

Peak area [\%] of plant material sampling localities

\begin{tabular}{|c|c|c|c|c|c|c|}
\hline & $\mathrm{RI}^{\mathrm{a}}$ & Lomé & Lo-J.Bb & Adéticopé & Bassar & Sokodé \\
\hline Monoterpene hydrocarbons & & 3.0 & 12.9 & 1.7 & 0.8 & 4.2 \\
\hline a-Pinene & 941 & 0.2 & 0.5 & & & 0.4 \\
\hline Sabinene & 976 & 0.3 & 0.6 & & & \\
\hline Myrcene & 993 & 0.3 & 0.6 & & & 0.4 \\
\hline P-Cymene & 1030 & & 0.9 & & & 0.5 \\
\hline Limonene & 1033 & 0.2 & 6.2 & 1.5 & 0.8 & 0.4 \\
\hline (Z)- $\beta$-Ocimene & 1046 & & 3.2 & & & 0.7 \\
\hline (E)-Cis-ocimene & 1058 & 1.8 & & 0.2 & & \\
\hline$\gamma$-Terpinene & 1068 & 0.2 & & & & 0.2 \\
\hline Terpinolene & 1100 & 0.2 & 1.0 & & & 1.5 \\
\hline Oxygenated monoterpenes & & 6.0 & 6.0 & 3.4 & 22.2 & 49.1 \\
\hline 1,8 Cineole & 1023 & 2.3 & & & & 3.6 \\
\hline Linalool & 1099 & 1.7 & & 2.9 & 17.3 & 41.2 \\
\hline Camphor & 1146 & 0.7 & & 0.5 & 1.3 & 0.5 \\
\hline Terpineol-4 & 1171 & 0.5 & & & & 2.5 \\
\hline Estragole & 1198 & 85.5 & & 10.0 & & 22.2 \\
\hline t-Anethole & 1253 & & & 32.6 & 74.6 & \\
\hline Carvacrol & 1273 & & & & 2.7 & \\
\hline Thymol & 1290 & & & & 0.5 & \\
\hline Bornyl acetate & 1289 & 0.2 & & & 0.5 & 0.9 \\
\hline Methyleugenol & 1293 & 0.4 & 74.5 & 42.3 & & \\
\hline Geranyl formiate & 1381 & 0.5 & & & & 0.4 \\
\hline Sesquiterpene hydrocarbons & & 3.7 & 5.3 & 6.3 & 2.3 & 13.5 \\
\hline$\beta$-Elemene & 1387 & 0.4 & & 0.3 & & 1.2 \\
\hline$\beta$-Caryophyllene & 1420 & 0.4 & & & & 0.2 \\
\hline (E)-a-Bergamotene & 1440 & 1.6 & & 3.6 & 0.6 & 7.6 \\
\hline a-Caryophyllene & 1452 & & & 0.3 & & 0.4 \\
\hline Germacrene D & 1487 & 0.3 & 0.6 & 0.2 & & 0.6 \\
\hline$\beta$-Selinene & 1493 & & & 0.2 & & 0.8 \\
\hline a-Zingiberene & 1494 & & & 0.4 & & \\
\hline Bicyclogermacrene & 1502 & 0.1 & & & & 0.4 \\
\hline a-Muurolene & 1508 & 0.3 & 0.6 & & & 0.9 \\
\hline Germacrene A & 1513 & 0.6 & & 0.4 & & 0.1 \\
\hline$\gamma$-Cadinene & 1514 & 0 & 4.1 & 0.9 & 1.7 & 1.4 \\
\hline Oxygenated sesquiterpenes & & 0.5 & & 3.7 & & 0.4 \\
\hline$\Gamma$-Cadinol & 1619 & 0.5 & & 3.7 & & 0.4 \\
\hline Total identified (\%) & & 98.6 & 92.3 & 99.7 & 100.0 & 89.4 \\
\hline
\end{tabular}

The experimental data in Table II show that all fungal strains tested were sensitive to the metyleugenol type of basil oil, but dermatophytes and pathogenic yeasts were more particularly affected. Hence, markedly low MICs $(80 \mu \mathrm{L} / \mathrm{L})$ were recorded with T. mentagrophytes var mentagrophytes. Along with dermatophytes, 


\begin{tabular}{|c|c|c|c|c|c|c|c|c|}
\hline \multicolumn{9}{|c|}{ Table III } \\
\hline \multicolumn{9}{|c|}{ Antibacterial activities of different basil essential oils chemotypes from Togo } \\
\hline \multirow[t]{3}{*}{ Cutaneous bacterial strains } & \multicolumn{8}{|c|}{$\mathrm{MIC}^{\mathrm{a}}(\mathrm{mL} / \mathrm{L})$} \\
\hline & \multicolumn{5}{|c|}{ Basil oils chemotypes } & \multirow[t]{2}{*}{ Linalol } & \multirow{2}{*}{$\begin{array}{l}\text { Méthyl } \\
\text { eugénol }\end{array}$} & \multirow[t]{2}{*}{ Estragole } \\
\hline & $\mathrm{Ob}^{1 \mathrm{~b}}$ & $\mathrm{Ob}^{2}$ & $\mathrm{Ob}^{3}$ & $\mathrm{Ob}^{4}$ & $\mathrm{Ob}^{5}$ & & & \\
\hline \multicolumn{9}{|l|}{ Feet microflora } \\
\hline Staphylococcus epidermidis (L1S2)c & $>500$ & $>500$ & 200 & 300 & $>500$ & $>500$ & $>500$ & $>500$ \\
\hline S. hominis (L8S2) & $>500$ & $>500$ & 200 & 400 & $>500$ & $>500$ & $>500$ & $>500$ \\
\hline S. cohnii* (L6S3) & $>500$ & $>500$ & 150 & 300 & $>500$ & $>500$ & $>500$ & $>500$ \\
\hline Coryneform gr. B (L 16C3)c & $>500$ & 400 & 100 & 300 & $>500$ & $>500$ & $>500$ & $>500$ \\
\hline Coryneform gr. C (L3C3 $)^{c}$ & $>500$ & $>500$ & 150 & 250 & $>500$ & $>500$ & $>500$ & $>500$ \\
\hline Coryneform gr. D2 (L19C1)c & $>500$ & 500 & 150 & 200 & $>500$ & $>500$ & $>500$ & $>500$ \\
\hline Micrococcus sedentarius (L7B5) c & $>500$ & 400 & 200 & 300 & 500 & $>500$ & $>500$ & $>500$ \\
\hline Acinetobacter sp. (LLH5DC1) & $>500$ & 500 & 300 & 400 & 400 & $>500$ & 500 & $>500$ \\
\hline Moraxella sp. (LH7SV1) & $>500$ & 500 & 250 & 500 & $>500$ & 400 & $>500$ & $>500$ \\
\hline Alcaligenes sp. (LH4TV1) & $>500$ & 400 & 300 & 300 & 500 & $>500$ & $>500$ & $>500$ \\
\hline \multicolumn{9}{|l|}{ Armpits microflora } \\
\hline Staphylococcus xylosus (IP 8166) & $>500$ & $>500$ & 300 & 400 & $>500$ & $>500$ & $>500$ & $>500$ \\
\hline S. haemolyticus (IP 8156)c & $>500$ & $>500$ & 200 & 300 & $>500$ & $>500$ & $>500$ & $>500$ \\
\hline Corynebacterium xerosis (IP5216)c & $>500$ & $>500$ & 150 & 250 & $>500$ & $>500$ & $>500$ & $>500$ \\
\hline Micrococcus luteus (L1C5) a & $>500$ & $>500$ & 400 & 500 & $>500$ & $>500$ & $>500$ & $>500$ \\
\hline
\end{tabular}

percentages are listed in Table II.

Using the relative importance of the oils major constituents as classification criteria permitted to determine five chemotypes as listed below:

i) Estragole chemotype (sample from Lomé): It contained mainly estragole $(85.50 \%)$, with a little amount of 1,8 -cineole $(2.25 \%)$. The estragole content in this sample was similar to previous findings (Guenther, 1949; Baritaux et al., 1992; Yayi et al., 2001).

ii) Linalol-estragole chemotype (sample from Sokodé): this type of basil oil contained linalool (41.21\%), estragole $(22.17 \%)$ and (E)-a-bergamotene $(7.56 \%)$ as major constituents. This chemotype was very close to the European type previously reported by other workers in Nigeria (Ekundayo et al., 1987) and in Benin (Yayi et al., 2001).

iii) Methyleugenol chemotype (sample from Botanical garden, UL): This basil oil type contained mainly methyleugenol $(74.45 \%)$, limonene $(6.22 \%)$, $\gamma$-cadinene $(4.07 \%)$ and $(Z)-\beta$-ocimene $(3.16 \%)$.

Antibacterial activities are shown in Table III.

\section{Conclusion}

The prospective investigation of the percentage composition of $O$. basilicum essential oils along with the evaluation of their antimicrobial properties on human normal cutaneous microflora bacterial and fungal strains is quite a typical applied research. The ultimate goal of this type of investigation is to help protect plant biodiversity and validate on a scientific basis the potential of some valuable species whether for food or non-food applications. The present study has shown that it is feasible to use some kinds of the leaf essential oil of $\mathrm{O}$. basilicum growing in Togo as a natural powerful antimicrobial ingredient whether in traditional or in modern medicines as well as in cosmetics. Such oils are the methyleugenol and the methyleugenol/t-anethole types. Conversely, the estragole type, the linalool/estragole type, and the $t-$ anethole type, which were also included in the investigated samples, did show any useful antimicrobial properties.

\section{References}

Adams RP. Identification of essential oil components by gas 
chromatography/quadrupole mass spectroscopy. Carol Stream, Ilinois, Allured Publishing Corporation, 2001.

Adjanohoun E, Ahyi MRA, Aké Assi L, Akpagana K, Chibon P, El-Hadj A, Eymen I, Goutote E, Ginko S, Hodouto KK, Hougnon P, Keita A, Kéoula Y, Klouga-Ocloo WP, Lo I, Siamevi K, Taffame KK, Garba M, Gassita JN, Gbeassor M. Médecine traditionnelle et Pharmacopée: Contribution aux études ethno-botaniques et floristiques du Togo. ACCT, Paris, 1986.

Albuquerque UP. de Taxonomia e ethnobotânica do gênero Ocimum L. (Lamiaceae) no Nordeste do Brasil-renfêrencia especial para Pernambuco. Recife. Dissertação (Mestrado em Biologia Vegetal)- Centro de Ciencias Biológicas, Universidade Federal de Pernambuco, 1996, p 125.

Archtander S. Perfume and flavour material of natural origin. Carol Steam, Allured Publishing Corporation, 1994, p 81.

Alvarez P, Enriquez AM, Toro C, Martinez I, Buhigas I, de Miguel S, Lago M, Puente S, del Palacio A, Baquero M. Dermatomiucosis de importación por Scytalidium dimidiatum: A propósito de tres casos. Rev Iberoam Micol. 2000; 17: 102-06.

Baba-Moussa F, Koumaglo K, Ayédoun K, Akpagana K, Moudachirou M, Bouchet P. Activité antifongique d'huiles essentielles extraites au Bénin et au Togo. Cryptogamie, Mycol. 1997; 18: 165-68.

Baritaux O, Richard H, Touche J, Dersbesy M. Effects of drying and storage of herbs and spices on the essential oil. Part I. Basil, O. basilicum L. Flav Fragr J. 1992; 7: 227-71. http:// dx.doi.org/10.1002/ffj.2730070507 http://dx.doi.org/ $10.1002 /$ ffj. 2730070411

Benjilali B, Tantaoui-Elaraki A, Ismaïlou-Alaoui M, Ayadi A. Méthode d'étude des propriétés antiseptiques des huiles essentielles par contact direct en milieu gélosé. Plant Méd Phytother. 1986; 20: 155-67.

Berrada M, Ait Igri M, Il Idrissi A, Bellakdar. Contribution à l'analyse de l'huile essentielle d'un cultivar d'Ocimum basilicum L. du Maroc. Al Buruniya. Rev Mar Pharm. 1987; 3: 137-44.

Bergogne-Bérézin E. The increasing significance of outbreaks of Acinetobacter spp: The need for control and new agents. J Hosp Infect. 1995; 30: 441-52.http://dx.doi.org/ 10.1016/0195-6701(95)90048-9 PMid:7560983

Chaumont JP, Leger D. Propriétés antifongiques de quelques phénols et de composés chimiquement très voisins. Relations structure-activité. Plant Med Phytother. 1989; 23: 124-28.

Chaumont JP, Mandin D, Sanda K, Koba K, De Souza C. Activités antimicrobiennes de cinq huiles essentielles de lamiacées togolaises vis à vis de germes représentatifs de la microflore cutanée. Acta Bot Gallica. 2001; 148: 93-101.

Center for Disease Control and Prevention (CDC). National nosocomial infections surveillance system report. Data sumary from January 1990-May 1990. Am J Infect Control. 1999; 27: 520-32. http://dx.doi.org/10.1016/S0196-6553(99) 70031-3 PMid:10586157

Craveiro AA, Matos FJ, Alencar JW. A simple and inexpensive steam generator for essential oils extraction. J Chem Ed. 1976; 53: 652.

Darrah H. Investigation on cultivars of Basils (Ocimum). Econ Bota. 1974; 28: 63-67.

Ekundayo O, Laakso I, Oguntimein B, Okogun JL, Elujoba A, Hulbinen A. Essential oil of Ocimum basilicum from Nigeria. Acta Pharm Fen. 1987; 96: 101-06.

Friedman M, Henika PR, Mandrell RE. Bactericidal activities of plant essential oils and some of their isolated constituents against Campylobacter jejuni, Escherichia coli, Listeria monocytogenes, and Salmonella enterica. J Food Prot. 2002; 65: 1545-60.

Griffin SG, Markham JL, Leach DN. An agar dilution method for the determination of the minimum inhibitory concentration of essential oils. J Essent Oil Res. 2000; 12: 24955 .

Guenther E. The essential oils. Vol. 2. New York, Van Nostrand, 1949, pp 16-18, 503-05.

Kayibou G. Les Eucalyptus du Congo. Variations inter et intraspécifiques du rendements et de la composition de leurs huiles essentielles. Thèse de doctorat Université de Montpellier II, France, 1992, p 112.

Ketoh KG, Glitoh AI, Huignard J. Susceptibility of the bruchus Callosobruchus maculatus (Coleoptera: Bruchidae) and its parasitoid Dinarmus basalis (Hymenopterae: Pteromatidae) to three essential oils. J Econ Entomol. 2002; 95: 174-82.

Keita SM, Vincent C, Schmit J, Arnason JT, Belanger A. Efficacy of oil of Ocimum basilicum L. and O. gratissimum L. applied as an insecticidal fumigant and powder to control Callosobruchus maculatus (Fab). J Stored Prod Res. 2001; 37: 339-49. http://dx.doi.org/10.1016/S0022-474X(00)00034-5

\section{PMid:11463396}

Kondjoyan N, Berdagué JL. A compilation of relative retention indices for the analysis of aromatic compounds. Ed. Laboratoire Flaveur, INRA de Theix, France, 1996.

Koumaglo K, Dotse K, Akpagana K, Garneau FX, Gagnon H, Jean IF, Moudachirou M, Addae-Mensah I. Analyse des huiles essentielles de deux plantes aromatiques du Togo. Riv Ital EPPOS. 1996; 7: 680-91.

Marshall J, Leening JP, Holland KT. The cutaneous microbiology of normal human feet. J Appl Bacteriol. 1987; 62: 39-46.

Marshall J, Holland KT, Gribbon EM. A comparative study of cutaneous microflora of normal feet with low and high levels of odour. J Appl Bacteriol. 1988; 65: 61-68.

Moudachirou M, Ayedou MA, Gbenou J, Garneau FX, Koumaglo KH, Mensah-Addae I. Composition chimique des huiles essentielles des feuilles de Clausena anisata récoltées dans la sous-region Bénin-Togo-Ghana. J Soachim. 1997; 3: 49-54.

Okunde AL, Olaifa JL. Estragole: An acute toxic principle from the volatile oil of the leaves of Clausena anisata. J Nat Prod. 1987; 50: 990-91. http://dx.doi.org/10.1021/np50053a046

PMid:3437289 
Ouaffak L, Gati A, Lyagoubi M. Les teignes du cuir chevelu dans les écoles Primaires de Khermisset (Maroc). J Mycol Méd. 2001; 114: 181-84.

Paton A. A synopsis of Ocimum L. (Labiatae) in Africa. Kew Bull. 1992; 47: 403-36. http:/ / dx.doi.org/10.2307/4110571

Rennie PJ, Gower DB, Holland KT. In vitro studies of human axillary odour and cutaneous microflora. Br J Dermatol. 1991; 124: 596-602. http://dx.doi.org/10.1111/j.13652133.1991.tb04958.x PMid:2064946

Sanda K, Koba K, Nambo P, Gaset A. Chemical investigation of Ocimum species growing in Togo. Flav Fragr J. 1998; 13: 226-32. http://dx.doi.org/10.1002/(SICI)1099-1026 (1998070)13:4\%3c226::AID-FFJ717\%3e3.0.CO;2-H http:// dx.doi.org/ 10.1002/(SICI)1099-1026(1998070)13:4\% 3c226::AID-FFJ717\%3e3.3.CO;2-8

Vandemeulebroucke BT, Mounkassa B, Deloye J, Jousserand P, Poujade F, Petithory JC. Teignes du cuir chevelu en milieu scolaire rural au Mali. J Mycol Med. 1999; 92: 11-13.

Viollon C, Chaumont JP. Antifungal properties of essential oils and their main components upon Cryptococcus neoformans. Mycopathologia 1994; 128: 151-53. http://dx.doi.org/ 10.1007/BF01138476 PMid:7739729

Yayi E, Moudachirou M, Chalchat JC. Chemotyping of three Ocimum species from Benin: O. basilicum, O. canum and $O$. gratissimum. J Essent Oil Res. 2001; 13: 13-17. 